\title{
Bioactivity and mechanical properties of nickel-incorporated hydrogenated carbon nanocomposite thin films
}

\author{
P. Vijai Bharathy, ${ }^{\text {a,b }}$ D. Nataraj, ${ }^{a *}$ Q. Yang ${ }^{b}$ and M. S. R. N. Kiran ${ }^{c}$
}

In this paper, the influence of nickel incorporation on the mechanical properties and the in vitro bioactivity of hydrogenated carbon thin films were investigated in detail. Amorphous hydrogenated carbon $(\mathrm{a}-\mathrm{C}: \mathrm{H})$ and nickel-incorporated hydrogenated carbon $(\mathrm{Ni} / \mathrm{a}-\mathrm{C}: \mathrm{H})$ thin films were deposited onto the Si substrates by using reactive biased target ion beam deposition technique. The films' chemical composition, surface roughness, microstructure and mechanical properties were investigated by using XPS, AFM, TEM, nanoindentation and nanoscratch test, respectively. XPS results have shown that the film surface is mainly

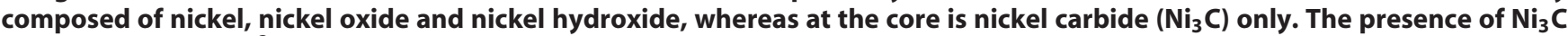
has increased the $\mathrm{sp}^{2}$ carbon content and as a result, the mechanical hardness of the film was decreased. However, $\mathrm{Ni} / \mathrm{a}-\mathrm{C}: \mathrm{H}$ films shows very low friction coefficient with higher scratch-resistance behavior than that of pure a-C : H film. In addition, in vitro bioactivity study has confirmed that it is possible to grow dense bone-like apatite layer on $\mathrm{Ni} / \mathrm{a}-\mathrm{C}: \mathrm{H}$ films. Thus, the results have indicated the suitability of the films for bone-related implant coating applications. Copyright (C) 2011 John Wiley \& Sons, Ltd.

Keywords: amorphous hydrogenated carbon; nickel; reactive-biased target ion beam deposition; in vitro bioactivity; mechanical properties; nanoscratch

\section{Introduction}

Recently, much attention has been focused on analyzing the new form of carbon-based material for its biomedical properties. In general, carbon is the basic constituent of every biological entity and it posses multifunctional properties suitable for biomedical engineering applications. In addition to its excellent biocompatibility, bone bioactivity is an essential factor to consider the carbon-based material for bone implant coating applications. Thus, according to Kokubo and Takadama's ${ }^{[1]}$ definition of in vitro bioactivity, a bioactive material is a material which has to exhibit chemical bonding to living tissues upon the formation of a bonelike hydroxyapatite layer selectively after it is immersed in a simulated body solution. ${ }^{[1,2]}$ Previously, many studies have shown that the in vivo apatite formation can be reproduced in a simulated body fluid (SBF) environment which has almost the same ion concentrations as those of human blood plasma. ${ }^{[3]}$ As a result, it was speculated that the bone-forming cells might preferentially proliferate and differentiate to produce apatite and collagen on the bioactive material surface. Thus formed apatite might bond to the surface apatite as well as to the surrounding bone. Consequently, a tight chemical bond is formed between the material and the living bone through the apatite layer. ${ }^{[4]}$ This means that the in vivo bone bioactivity of a material can be predicted from the apatite formation on its surface in SBF.

Along with the bone bioactivity property, appropriate mechanical properties are highly essential and ideal material for bone implant coating applications. In this regard, coatings composed of crystalline/amorphous nanophase mixture have recently attracted huge interest for its multifunctional properties. Especially, metal containing hydrogenated amorphous carbon $(\mathrm{M} / \mathrm{a}-\mathrm{C}: \mathrm{H})$ coatings have received considerable interest as nanocomposite coatings with nanosized crystalline metal or metal carbide clusters embedded in the amorphous carbon matrix. ${ }^{[4-6]}$ These nanocomposite coatings possess unusual combinations of mechanical and tribological properties such as high hardness and toughness, superior wear resistance and low friction which are often not attained in nanocrystalline coatings. ${ }^{[7]}$ In addition to these properties, the biological behavior (bioactivity) of the coating is strongly influenced by the chemical properties at the surface. It has been reported that the biomedical properties of the a-C:H films can be modified by adding suitable carbide and noncarbide-forming materials which includes silicon $(\mathrm{Si})$, titanium $(\mathrm{Ti})$, calcium $(\mathrm{Ca})$, phosphorus $(\mathrm{P})$, boron $(\mathrm{B})$, nickel $(\mathrm{Ni})$ and nitrogen $(\mathrm{N}) .^{[8-16]}$ Among these doping materials, carbide-forming metals plays a significant role in altering the mechanical and the bioactivity of the coating to a greater extent. In general, these additives posses an ability to tune the surface-related properties of the $\mathrm{a}-\mathrm{C}: \mathrm{H}$ thin films suitable for biomedical applications. These studies show that the microstructure and the properties of the nanocomposite films were highly dependent on the type of metal and its concentration in the carbonaceous network. ${ }^{[8-10]}$

Our present research interest is mainly focused to study the in vitro bioactivity (bone-bonding ability) and mechanical

* Correspondence to: D. Nataraj, Thin films and Nanomaterials Lab, Department
of Physics, Bharathiar University, Coimbatore, India. E-mail:de.natraj@gmail.com

a Thin films and Nanomaterials Lab, Department of Physics, Bharathiar University, Coimbatore, India

b Department of Mechanical Engineering, University of Saskatchewan, Saskatoon, Canada

c Department of Materials Engineering, Indian Institute of Science, Bangalore, India 
properties of pure $\mathrm{a}-\mathrm{C}: \mathrm{H}$ and $\mathrm{Ni} / \mathrm{a}-\mathrm{C}: \mathrm{H}$ nanocomposite thin films. Several deposition methods such as hybrid reactive magnetron sputtering, ${ }^{[13]}$ pulsed laser ablation, ${ }^{[14]}$ electrodeposition ${ }^{[17]}$ and hybrid plasma enhanced chemical vapor deposition method ${ }^{[18]}$ have been employed to synthesize nickel-incorporated hydrogenated carbon thin films. Biased target ion beam deposition is a new deposition method mainly used for the fabrication of ultrathin (with high adhesion) films. The main advantage of this method is that it is possible to have a controlled atomistic intermixing between two phases to prepare nanoclusters using a low energy ion beam with few $\mathrm{eV}$ at room temperature. Reactive biased target ion beam deposition (RBTIBD) technique is capable of precise control on the concentration of metal, low contamination effect and thickness uniformity. ${ }^{[19,20]}$ Hence in the present work, the Ni/a$\mathrm{C}: \mathrm{H}$ films with different nickel fractions were deposited at room temperature by using RBTIBD method. The chemical composition, microstructure and surface topography of the $\mathrm{Ni} / \mathrm{a}-\mathrm{C}: \mathrm{H}$ films were systematically investigated. It was interesting to see that most of the nickel reacts with carbon to form crystalline nickel carbide and, in addition to that, the incorporated nickel initiates more number of $\mathrm{sp}^{2}$ than $\mathrm{sp}^{3}$ hybridized bonding states in the $\mathrm{a}-\mathrm{C}: \mathrm{H}$ matrix. The influence of $\mathrm{Ni}$ incorporation on the mechanical properties and the in vitro bioactivity was investigated in detail.

\section{Experimental details}

\section{Film deposition}

Amorphous hydrogenated carbon and nickel-incorporated hydrogenated carbon thin films were deposited onto a p-type (100) Si substrate by using reactive-biased target ion beam deposition method (RBTIBD). ${ }^{[21]}$ After placing the Si wafers on the substrate holder, the deposition chamber was pumped down to the base pressure of $2 \times 10^{-7}$ Torr and all the depositions were carried out at a working pressure of $6 \times 10^{-4}$ Torr (approx.). Also, the substrate stage was placed at an angle of $45^{\circ}$ and it was rotated about its axis at a constant speed of $3 \mathrm{rpm}$ to achieve better uniformity. High purity (99.9995\%) methane $\left(\mathrm{CH}_{4}\right)$ and Argon ( $\left.\mathrm{Ar}\right)$ gases were mixed in the ratio of $1: 1$ and introduced into end-hall ion source I to deposit pure $\mathrm{a}-\mathrm{C}: \mathrm{H}$ thin film. Similarly, for the deposition of $\mathrm{Ni} / \mathrm{a}-\mathrm{C}: \mathrm{H}$ nanocomposite films, the hydrocarbon ion beam with an ion energy of $30 \mathrm{eV}$ was directed towards the substrate to deposit $\mathrm{a}-\mathrm{C}: \mathrm{H}$ film, at the same time nickel was sputtered by using high purity Ar gas using another end-hall ion source II. The Ni sputtering yield was increased by increasing the negative bias voltage from -300 to $-700 \mathrm{~V}$. During the deposition, the argon/methane gas ratio and ion beam energy were fixed constant, only the Ni target bias voltage was increased to alter the $\mathrm{Ni}$ sputtering yield. The deposition duration was kept as $45 \mathrm{~min}$ in order to obtain a thickness of $100 \mathrm{~nm}$ (approx.) for all $\mathrm{Ni} / \mathrm{a}-\mathrm{C}: \mathrm{H}$ thin films. The thickness of the films was measured to be around $100 \pm 5 \mathrm{~nm}$ using the surface profilometer measurements.

\section{Characterization techniques}

The composition of the films was determined using a VG-Microtech Multilab 3000 X-ray photoelectron spectroscope (XPS, operating with $\mathrm{Mg} \mathrm{K} \alpha(300 \mathrm{~W}) \mathrm{X}$-ray source and detecting chamber pressure of below $10^{-8}$ Torr). The spectra were collected at pass energy of $50 \mathrm{eV}$. An Ar+ ion beam was used to etch the samples' surface to a depth of about $15 \mathrm{~nm}$, so as to remove contaminants before commencing the XPS measurement. The intensities were estimated by calculating the integral of each peak, after subtraction of the S-shaped background, and by fitting the experimental curve to a combination of Lorentzian (30\%) and Gaussian (70\%) lines by using XPSpeak software. The relative Ni atom concentration in the carbon matrix was calculated from XPS signals of Ni (2p) with respect to $C(1 \mathrm{~s})$ core levels. Transmission electron microscopy (TEM) and high resolution transmission electron microscopy (HRTEM) investigations were carried out by a $200 \mathrm{kV}$ Philips CM20 analytical microscope and a 300 kV JEOL 3010 microscope, respectively. Fast Fourier transform (FFT) was used to analyze the lattice spacing of the crystalline phase in the films. Surface topography and roughness of the deposited films were estimated over an area of $1 \mu \mathrm{m} \times 1 \mu \mathrm{m}$ by using atomic force microscopy (VEECO diCaliber instrument) in tapping mode. The hardness of a$\mathrm{C}: \mathrm{H}$ and $\mathrm{Ni} / \mathrm{a}-\mathrm{C}: \mathrm{H}$ thin films was determined by nanoindentation (Triboindenter of Hysitron, Minneapolis, USA) in a load controlled mode. A partial unloading function ( $50 \%$ of the peak load) was used to obtain the depth-dependent hardness of the film between the loading ranges from 200 to $5000 \mu \mathrm{N}$. Images of the indents were captured using the same indenter in the scanning probe microscope (SPM) mode. Hardness of the films was calculated from the load-displacement curves using the Oliver-Pharr analysis. ${ }^{[22]}$ In order to find the true hardness of these thin films with more accuracy, Korsunsky fitting model was used. The advantage of this method is that it is possible to determine the substrate-effect free coatings hardness. For soft films on hard substrates, the influence of substrate is unavoidable during hardness measurement and, therefore, this method assumes importance in obtaining the true hardness of the film. ${ }^{[23]}$ This Korsunsky's model is based on energy expenditure during an indentation and the final equation is given by ${ }^{[24]}$

$$
H_{\mathrm{c}}=H_{\mathrm{s}}+\left(H_{\mathrm{f}}-H_{\mathrm{s}}\right) /\left(1+k \beta^{2}\right)
$$

where

$\beta$ is the relative indentation depth, $k$ is a constant related to the film thickness, $H_{\mathrm{f}}$ is film hardness, $H_{\mathrm{s}}$ is substrate hardness and $H_{\mathrm{c}}$ is the composite hardness. According to this model, the extrapolation of the curve to the vertical axes gives the hardness of the film. An average of 3 indentations was taken in each sample to determine the hardness value and fitted using Korsunsky model. The adhesion and friction coefficient of the nanocomposite thin films were evaluated by using a nanoscratch tester with a sharp diamond indent tip with a ramping load range between 0 and $1000 \mu \mathrm{N}$.

\section{Stimulated body fluid treatment}

The bioactivity of the thin film samples prepared by RBTIBD was evaluated by examining their apatite-forming ability in the simulated body fluid (SBF) medium. SBF was prepared by dissolving $\mathrm{NaCl}, \mathrm{NaHCO}_{3}, \mathrm{KCl}, \mathrm{K}_{2} \mathrm{HPO}_{4}, \mathrm{MgCl}_{2}, \mathrm{CaCl}_{2}$ and $\mathrm{Na}_{2} \mathrm{SO}_{4}$ in ultrapure water. ${ }^{[25,26]}$ The ion concentrations of $\mathrm{Na}^{+}, \mathrm{K}^{+}, \mathrm{Mg}^{2+}$, $\mathrm{Ca}^{2+}, \mathrm{Cl}^{-}, \mathrm{HCO}_{3}{ }^{-}, \mathrm{HPO}_{4}{ }^{2-}$ and $\mathrm{SO}_{4}{ }^{2-}$ were 142.0, 5.0, 1.5, 2.5, $147.8,4.2,1.0$ and $1.0 \mathrm{~mm}$, respectively. The solution was buffered at $\mathrm{pH} 7.4$ using Tris (hydroxymethyl amino methane) and $1 \mathrm{M}$ aqueous $\mathrm{HCl}$ at $37^{\circ} \mathrm{C}$. Amorphous hydrogenated carbon and Ni/a$\mathrm{C}: \mathrm{H}$ thin films samples were soaked in $15 \mathrm{ml}$ of $\mathrm{SBF}$ at $37^{\circ} \mathrm{C}$ for 1 , 7 and 28 days. Then the immersed samples were taken out, rinsed with ultrapure water and then dried in an oven for $30 \mathrm{~min}$ at $50^{\circ} \mathrm{C}$. After SBF treatment, the morphology and structure of the apatite formed on the surface of the film was studied using FEI Quanta 200 scanning electron microscope and Expert pro-PAN-Analytical X-ray diffraction (XRD) system, respectively. All the bioactivity 
Table 1. Surface chemical composition of $\mathrm{Ni}$ and oxygen on air exposed a-C: $\mathrm{H}$ and $\mathrm{Ni} / \mathrm{a}-\mathrm{C}: \mathrm{H}$ films prepared at different target bias voltage

\begin{tabular}{|lccc|}
\hline Sample & $\begin{array}{c}\text { Target bias } \\
\text { voltage }\end{array}$ & $\begin{array}{c}\text { Ni concentration } \\
\text { (at.\%) }\end{array}$ & $\begin{array}{c}\text { Oxygen concentration } \\
\text { (at.\%) }\end{array}$ \\
\hline $\mathbf{a}-\mathbf{C}-\mathbf{H}$ & - & - & 7.6 \\
$\mathbf{N i}-\mathbf{1}$ & $-300 \mathrm{~V}$ & 1.2 & 14.52 \\
$\mathbf{N i}-\mathbf{2}$ & $-400 \mathrm{~V}$ & 2.1 & 14.8 \\
$\mathbf{N i}-\mathbf{3}$ & $-500 \mathrm{~V}$ & 2.4 & 14.38 \\
$\mathbf{N i}-\mathbf{4}$ & $-600 \mathrm{~V}$ & 3 & 16.06 \\
$\mathbf{N i}-\mathbf{5}$ & $-700 \mathrm{~V}$ & 3.8 & 16.5 \\
\hline
\end{tabular}

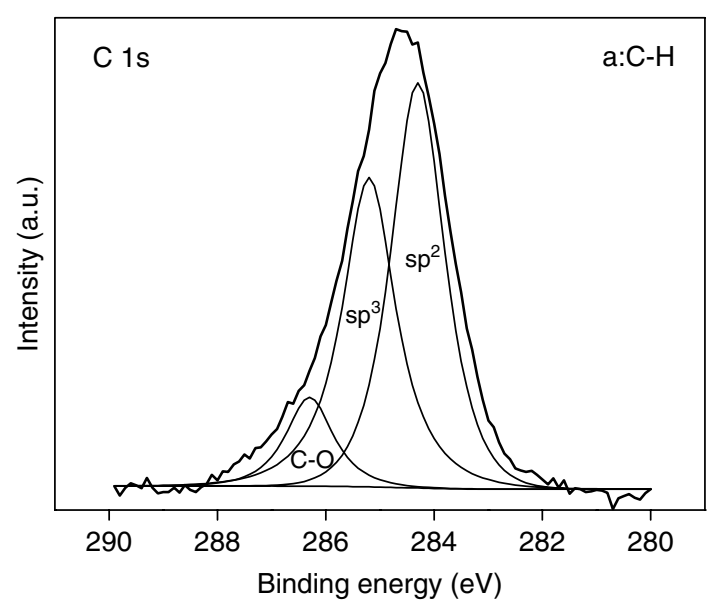

Figure 1. Typical $C$ 1s XPS spectra for unetched pure $a-C: H$ thin film.

experiments were performed in quintuplicate, by running five parallel independent tubes.

\section{Results and discussion}

\section{Surface chemical composition analysis}

The chemical composition and bonding nature of pure $\mathrm{a}-\mathrm{C}: \mathrm{H}$ and $\mathrm{Ni} / \mathrm{a}-\mathrm{C}: \mathrm{H}$ thin films were studied by using XPS analysis. The relative elemental concentration of nickel gets increased from 1.2 to 3.8 at.\% with increase in target bias voltage from -300 to $-700 \mathrm{~V}$. We have prepared five different samples with different $\mathrm{Ni}$ concentration and these corresponding films are named as $\mathrm{Ni}-1$, $\mathrm{Ni}-2, \mathrm{Ni}-3, \mathrm{Ni}-4$ and $\mathrm{Ni}-5$. Table 1 shows the Ni concentration and the corresponding target bias voltage. The atomic percentage of oxygen increases with an increase in the Ni concentration. This increase is due to unreacted $\mathrm{Ni}$ metal being exposed to air after deposition.

\section{$\mathrm{C} 1 \mathrm{~s}$ and $\mathrm{Ni} 2 p_{3 / 2}$ XPS spectra of air exposed $\mathrm{Ni} / \mathrm{a}-\mathrm{C}: \mathrm{H}$ films}

The effect of $\mathrm{Ni}$ incorporation on the chemical bondings of a$\mathrm{C}: \mathrm{H}$ matrix was studied in detail. Figure 1 shows the $\mathrm{C} 1 \mathrm{~s}$ XPS spectrum of air-exposed pure $\mathrm{a}-\mathrm{C}: \mathrm{H}$ thin film. It was found that the deconvoluted $\mathrm{C} 1 \mathrm{~s}$ spectrum of pure $\mathrm{a}-\mathrm{C}: \mathrm{H}$ film was mainly composed of three different components with binding energy values at $\sim 284.5 \mathrm{eV}, \sim 285.2 \mathrm{eV}$ and $\sim 286.2 \mathrm{eV}$ corresponding to $\mathrm{C}$ $\mathrm{sp}^{2}, \mathrm{C} \mathrm{sp}{ }^{3}$, and $\mathrm{C}-\mathrm{O}$ bonds, respectively. Figure $2(\mathrm{a})$ shows the $\mathrm{C} 1 \mathrm{~s}$ XPS spectrum of $\mathrm{Ni} / \mathrm{a}-\mathrm{C}: \mathrm{H}$ film. It was found that the deconvoluted

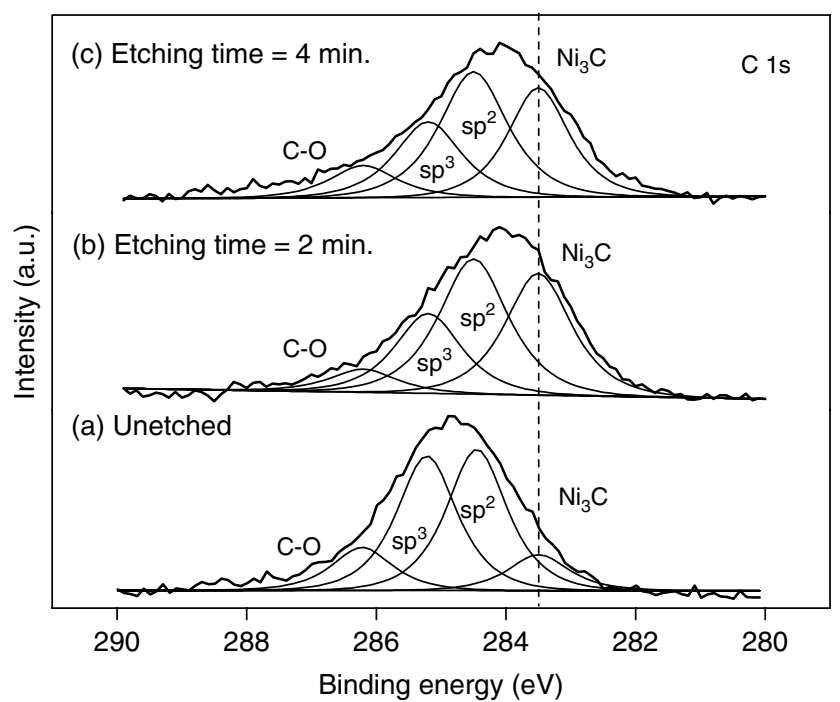

Figure 2. Deconvoluted C 1s XPS spectra for $\mathrm{Ni} / \mathrm{a}-\mathrm{C}: \mathrm{H}$ (Ni-2.4 at.\%) nanocomposite thin films with different etching times: (a) Unetched, (b) etching time $2 \mathrm{~min}$, and (c) etching time $4 \mathrm{~min}$.

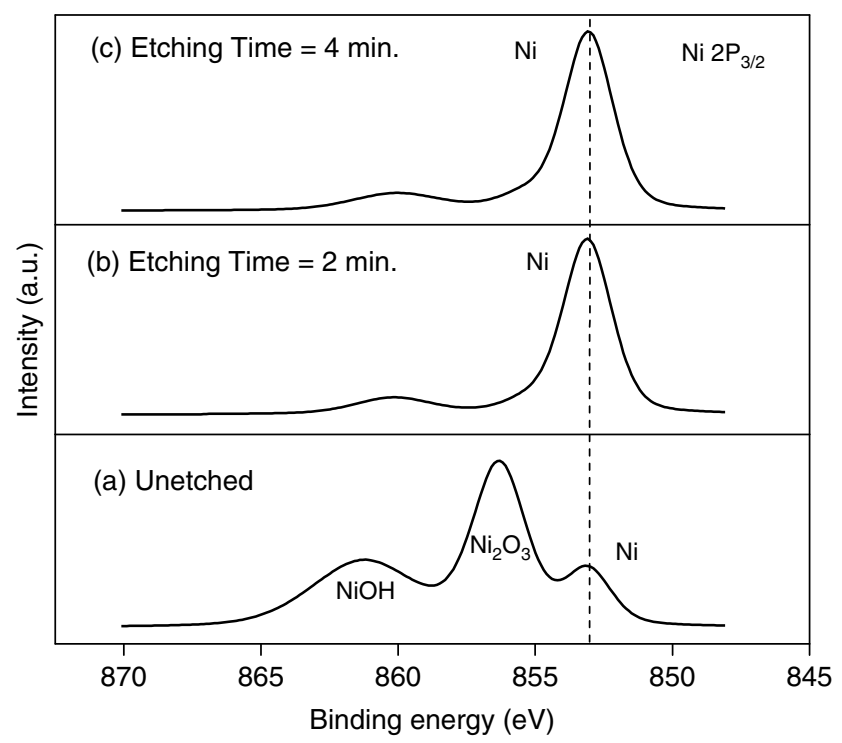

Figure 3. High-resolution $\mathrm{Ni} 2 \mathrm{p}_{3 / 2}$ XPS spectra for Ni/a-C:H (Ni-2.4 at.\%) nanocomposite thin films with different etching times: (a) Unetched, (b) etching time $2 \mathrm{~min}$, and (c) etching time $4 \mathrm{~min}$.

C 1s spectra of $\mathrm{Ni}$ incorporated a-C: $\mathrm{H}$ thin film was also composed with $\mathrm{C} \mathrm{sp}^{2}, \mathrm{Csp}$ and $\mathrm{C}-\mathrm{O}$ bonds. In addition to these peaks, $\mathrm{Ni}_{3} \mathrm{C}$ phase was also noticed due to the $\mathrm{Ni}$ incorporation in the carbon matrix. Irrespective of the nickel concentration, nickel carbide phase was found in all the $\mathrm{Ni} / \mathrm{a}-\mathrm{C}: \mathrm{H}$ nanocomposite thin films. Our result is in agreement with the results reported by others on the nickel containing a-C : H film. ${ }^{[27,28]}$ Upon comparison, the presence of $\mathrm{sp}^{2}$ and $\mathrm{sp}^{3}$ hybridization and their relative concentrations in $\mathrm{a}-\mathrm{C}: \mathrm{H}$ and $\mathrm{Ni} / \mathrm{a}-\mathrm{C}: \mathrm{H}$ thin film and this is to find the influence of $\mathrm{Ni}$ on the carbon matrix. It was found that with increasing $\mathrm{Ni}$, the relative fraction of $\mathrm{C} \mathrm{sp}{ }^{3}$ bonds decreases from 44.1 to $25.5 \%$. On the other hand, the $\mathrm{C} \mathrm{sp}{ }^{2}$ presences have relatively increased from 45.8 to $50.4 \%$, as an evidence of progressive graphitization in the nanocomposite films. 


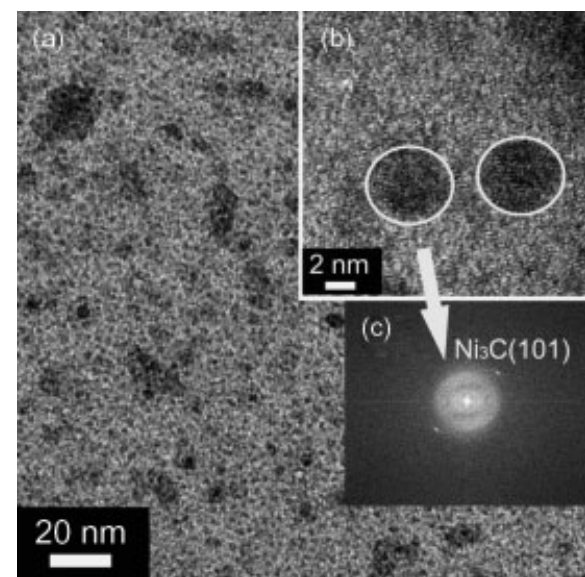

Figure 4. TEM image of $\mathrm{Ni} / \mathrm{a}-\mathrm{C}: \mathrm{H}$ : (a) plan view TEM image, (b) HRTEM image, and (c) FFT pattern of Ni-3 (Ni-2.4 at.\%) nanocomposite thin film.
To assess quantitatively the presence of different nickel bonding states in air-exposed $\mathrm{Ni} / \mathrm{a}-\mathrm{C}: \mathrm{H}$ nanocomposite films, the broad $\mathrm{Ni}$ $2 p_{3 / 2}$ core level spectra was deconvoluted (shown in Fig. 3(a)). It was found that all the films were composed of three different components with binding energy values at $\sim 852.9 \mathrm{eV}, \sim 856.1 \mathrm{eV}$ and $\sim 861.2 \mathrm{eV}$, corresponding to $\mathrm{Ni}, \mathrm{Ni}_{2} \mathrm{O}_{3}$ and $\mathrm{Ni}-\mathrm{OH}$ bonds, respectively. ${ }^{[28]}$ The presence of $\mathrm{Ni}$ and their corresponding nickel oxide phase gets increased with increase in target bias voltage. These results indicate a fact that a greater part of the surfaceexposed $\mathrm{Ni}$ is oxidized. A broad O1s spectra inbetween 529 to $534 \mathrm{eV}$ was observed from air-exposed $\mathrm{Ni} / \mathrm{a}-\mathrm{C}$ : $\mathrm{H}$ films (not shown here). Thus, observing the $\mathrm{O} 1 \mathrm{~s}$ spectra it was found that most of the atmospheric oxygen bound to $\mathrm{Ni}$ and carbon to form nickel oxide, carbonyl and $\mathrm{C}=\mathrm{O}$ bonds on the films surface.

\section{$\mathrm{C} 1 \mathrm{~s}$ and $\mathrm{Ni} 2 p_{3 / 2}$ XPS spectra of Ar etched Ni/a-C: $\mathrm{H}$ films}

Once the films are exposed to air after deposition, a gradual oxidation takes place in the first few days. In addition to that, the oxygen contamination on the surface of air-exposed $\mathrm{Ni} / \mathrm{a}-\mathrm{C}$ : $\mathrm{H}$ films

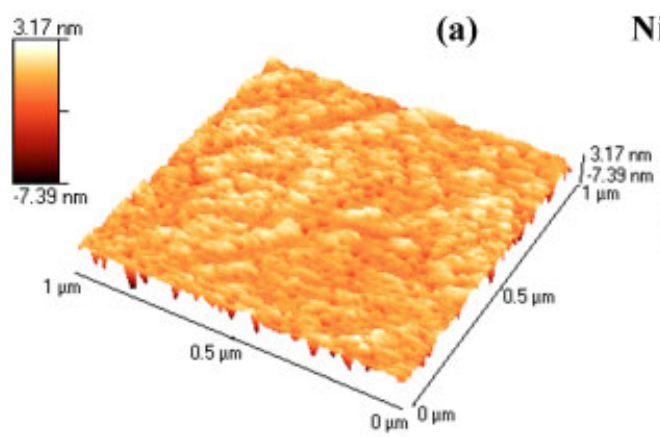

$\mathrm{Ni}-1$

(b)

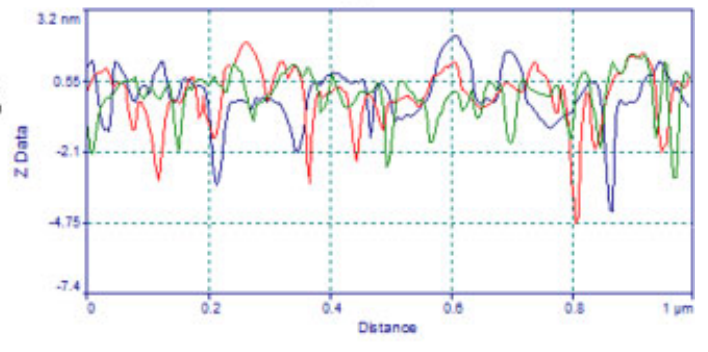

$\mathrm{Ni}-3$

(d)

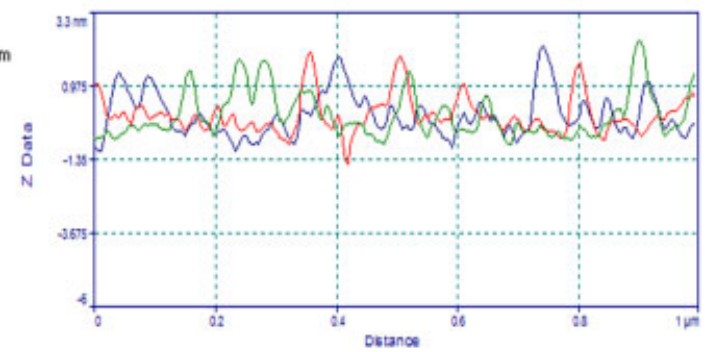

$\mathrm{Ni}-5$

(f)

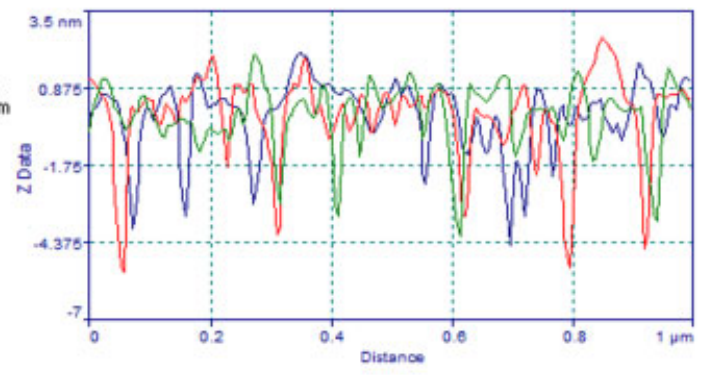

Figure 5. Surface topography of $\mathrm{Ni} / \mathrm{a}-\mathrm{C}: \mathrm{H}$ thin film showing 3D images and surface line profile plot of (a-b) Ni-1 (c-d) Ni-3 and (e-f) Ni-5 nanocomposite thin films. 

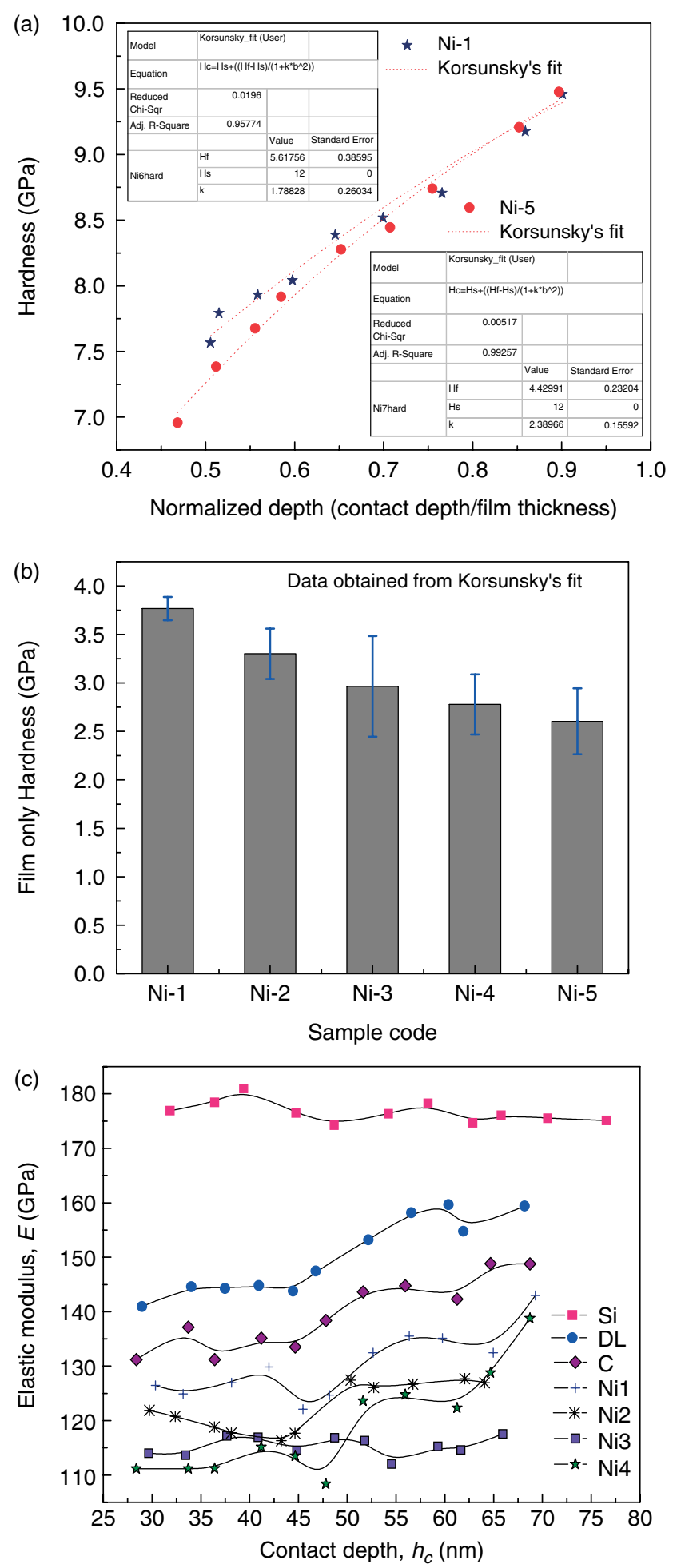

Figure 6. (a) Film-only hardness for $\mathrm{Ni} / \mathrm{a}: \mathrm{C}-\mathrm{H}$ films with different $\mathrm{Ni}$ concentration fitted using Korsunsky model. (Only Ni-1 and Ni-5 data were presented to avoid confusion and clumsiness in the figure. Dotted lines represent fit). (b) Shows the variation of 'Film-only hardness' with different nickel concentrations, obtained from composite hardness after Korsunky fit. (c) Variation of elastic modulus with varying nickel percentage in the $\mathrm{a}-\mathrm{C}: \mathrm{H}$ films. prevents us from evaluating the precise chemical composition of the nanocomposite thin films. In the present work, the oxygen contamination on the surface of the film was removed by etching the film by using Ar ions with energy of $1 \mathrm{KeV}$ for 2 and $4 \mathrm{~min}$. Figure 2(b) and (c) depicts the C 1s XPS spectra of Ni/a-C : $\mathrm{H}(\mathrm{Ni}-2.4$ at.\%) nanocomposite thin film etched for different durations (2 and $4 \mathrm{~min}$ ). Again, the deconvoluted $\mathrm{C} 1 \mathrm{~s}$ spectra of $\mathrm{Ni} / \mathrm{a}-\mathrm{C}: \mathrm{H}$ thin film shows four components: $\mathrm{C} \mathrm{sp}{ }^{2}, \mathrm{Csp}, \mathrm{C}-\mathrm{O}$ and $\mathrm{Ni}_{3} \mathrm{C}$. But by comparing the etched and unetched thin films, it was found that the intensity of $\mathrm{Ni}_{3} \mathrm{C}$ gets increased relatively. This result indicates that the surface-exposed $\mathrm{Ni}$ are oxidized. The presence of $\mathrm{Ni}_{3} \mathrm{C}$ was not prominent in unetched samples. Etched samples showed the prominent feature to be the $\mathrm{Ni}_{3} \mathrm{C}$ phase (shown in Fig. 2). From the $\mathrm{Ni} 2 \mathrm{p}_{3 / 2}$ spectrum (Fig. $3(\mathrm{~b})$ and (c)) of the etched thin film sample, it was again proved that most of the oxide phases disappeared completely.

\section{Structural analysis}

Figure 4 shows the plan view and HRTEM image of $\mathrm{Ni} / \mathrm{a}-\mathrm{C}: \mathrm{H}$ (Ni-2.4 at.\%) thin film. The plan view TEM image (Fig.4(a)), shows the presence of nanoclusters in a random distribution and embedded in the amorphous hydrogenated carbon matrix. In addition, the HRTEM image depicted in Fig. 4(b) shows that the metal nanoclusters are randomly distributed in the amorphous $\mathrm{a}-\mathrm{C}: \mathrm{H}$ matrix with an average size of $\sim 2 \mathrm{~nm}$. Furthermore, by using the FFT pattern (Fig. 4(c)), it was found that the incorporated $\mathrm{Ni}$ appears in the form of crystalline $\mathrm{Ni}_{3} \mathrm{C}$ (101) phase in the amorphous hydrogenated carbon matrix. A similar nickel carbide phase formation was also noticed by others. ${ }^{[13,28-30]}$

\section{Surface topography analysis}

Surface roughness and surface topography are the key factors influencing the bioactivity of amorphous hydrogenated carbon thin films. Hence, surface topography and roughness of pure $\mathrm{a}-\mathrm{C}: \mathrm{H}$ and $\mathrm{Ni} / \mathrm{a}-\mathrm{C}: \mathrm{H}$ thin films were studied by using AFM. Figure 5(a) - (f) shows the typical AFM (3D) images of $\mathrm{Ni} / \mathrm{a}-\mathrm{C}$ : H films with variable Ni concentrations measured over $1 \mu \mathrm{m} \times 1 \mu \mathrm{m}$ area by AFM. The pure a-C:H film shows a very smooth surface with a surface roughness value of around $0.25 \mathrm{~nm}$. With the incorporation of $\mathrm{Ni}$ concentration into the $\mathrm{a}-\mathrm{C}: \mathrm{H}$ matrix, the surface roughness increases to a maximum value of around $1.3 \mathrm{~nm}$ for $\mathrm{Ni} / \mathrm{a}-\mathrm{C}: \mathrm{H}$ (Ni-3.8 at.\%) film. In addition to that of surface roughness and surface topographic study, the line profile analysis was performed to retrieve the detailed information about the surface uniformity of the Ni/a-C:H thin films. Three lines are randomly chosen in three different places on the surface of the film to analyze their uniformity. It was clear that the film with higher Ni fraction shows more rough patterns than that of other $\mathrm{Ni} / \mathrm{a}-\mathrm{C}: \mathrm{H}$ nanocomposite thin films.

\section{Mechanical properties}

The hardness $(\mathrm{H})$ and elastic modulus $(\mathrm{E})$ details of Ni/a-C: $\mathrm{H}$ thin films were obtained and the results are shown in Fig. 6. It was interesting to note that at an indentation depth of $30 \mathrm{~nm}, \mathrm{Ni}$ incorporated a-C:H films exhibited a lower hardness value than that of pure a-C: $\mathrm{H}$ thin film $(H=26.5 \mathrm{GPa})$ and Si substrate, and this is irrespective of $\mathrm{Ni}$ concentration. This observation indirectly supports the increase in the concentration of $\mathrm{sp}^{2}$ carbon bonds in the Ni/a-C:H films, which was confirmed through XPS analysis. 

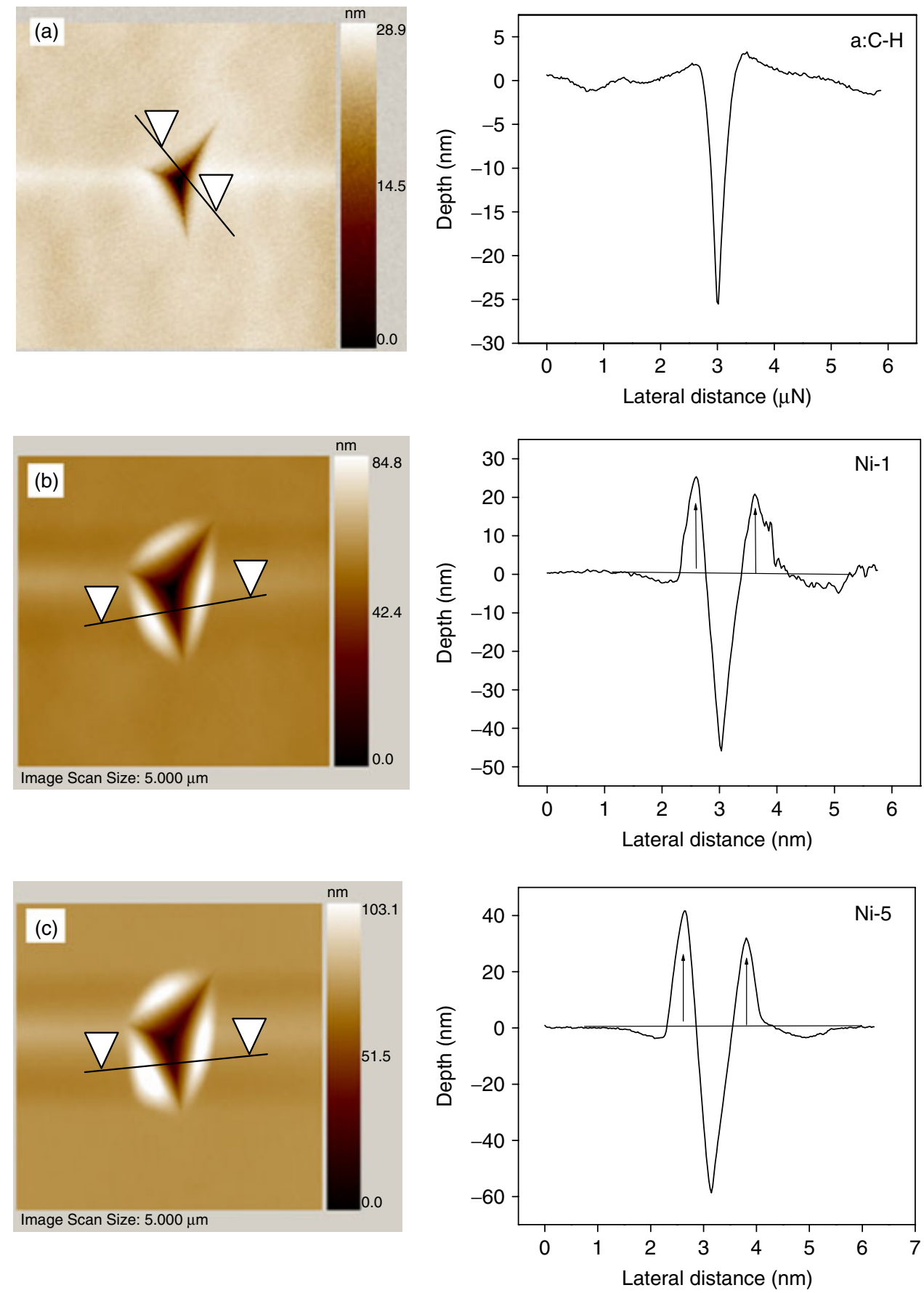

Figure 7. Surface topographies and their corresponding line profile on the residual indent impression of (a) a: $\mathrm{C}-\mathrm{H}$, (b) $\mathrm{Ni}-1$ and (c) Ni-5 thin films.

Since the hardness values of $\mathrm{Ni} / \mathrm{a}-\mathrm{C}: \mathrm{H}$ films are less than that of silicon substrate used, we have followed Korsunsky's model to find the 'film-only hardness' from composite hardness (film + substrate hardness). Korsunsky's fit to the $H$ values versus normalized depth obtained using O\&P method for $\mathrm{Ni}-1$ and $\mathrm{Ni}-5$ samples are shown in Fig. 6(a). The composite hardness of all the $\mathrm{Ni} / \mathrm{a}-\mathrm{C}: \mathrm{H}$ films increases from 7 to $9.5 \mathrm{GPa}$ with increase in indenter penetration depth. At higher indentation depths, the hardness values were approaching towards the hardness of the substrate (10 GPa for $\mathrm{Si}$ ). The film only hardness of $\mathrm{a}-\mathrm{C}: \mathrm{H}$ films with different nickel concentrations is shown in Fig. 6(b). It is clear that hardness values decrease with increasing nickel content in the films. The hardness of Ni-1 film was
3.8 GPa, whereas it decreased to 3.3, 2.9, 2.7 and finally $2.5 \mathrm{GPa}$ for $\mathrm{Ni}-2, \mathrm{Ni}-3, \mathrm{Ni}-4$ and $\mathrm{Ni}-5$ films, respectively. Among Ni-incorporated thin films, very low hardness value of $2.5 \mathrm{GPa}$ was observed for high $\mathrm{Ni}$-incorporated $\mathrm{a}-\mathrm{C}: \mathrm{H}$ thin film. The decrease in the hardness value is mainly due to the increase in $\mathrm{sp}^{2}$ content.

The mechanical hardness directly affects the materials plastic and elastic behavior of the films. ${ }^{[22]}$ So as to investigate this effect, we conducted two different experiments to monitor the plastic and elastic behavior. The plasticity of the films was tested by using indentation test and also through pile-up formation around the indented zone after indentation. In the present case, we have observed a large amount of material around the sides of the 


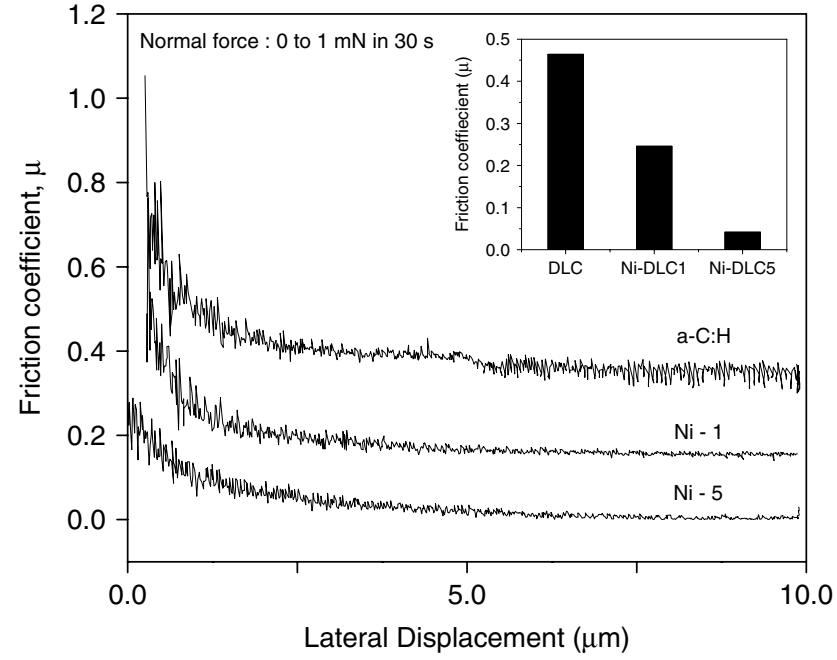

Figure 8. Variations of friction coefficient as a function of nickel concentration in $\mathrm{Ni} / \mathrm{a}-\mathrm{C}: \mathrm{H}$ thin with a ramping load from 0 to $1000 \mu \mathrm{N}$ in $30 \mathrm{~s}$. Inset with the friction coefficient value of $\mathrm{Ni} / \mathrm{a}-\mathrm{C}: \mathrm{H}$ films is given for eye guidance.

indenter. The height was almost one-third of the indentation depth. It was also found that the pile-up height increases with increasing nickel content in the a-C:H films (Fig. 7(a)-(c)). However, no pile-up formation was observed for Ni-free $\mathrm{a}-\mathrm{C}: \mathrm{H}$ film as shown in Fig. 7(a). From the above results it is clear that the incorporation of $\mathrm{Ni}$ in $\mathrm{a}-\mathrm{C}: \mathrm{H}$ film, enhances the plastic behavior. In general, similar kind of plastic behavior was usually observed in low-strain hardening materials as reported elsewhere. ${ }^{[31]}$

Elastic modulus, $E$, which is a measure of stiffness, followed the same trend as that of hardness, a well known relationship. ${ }^{[32]} \mathrm{A}$ decrease in $E$ observed from $\sim 140$ to $\sim 100 \mathrm{GPa}$ with increasing nickel content from 1.2 to 3.8 at.\%, respectively, as shown in Fig. 6(c). Nevertheless, the values presented in Fig. 6(c) are calculated from O\&P method, hence, we believe that they are also overestimated values because of the pile-up effect. To report precise values, elastic modulus was calculated from the projected contact area method using the image of residual indent impression; they are $88.7 \mathrm{GPa}$ for the $\mathrm{Ni}-1$ films and decreased to 81.5 for $\mathrm{Ni}-2,73.4$ for $\mathrm{Ni}-3,69.1$ for $\mathrm{Ni}-4$, and finally $56.7 \mathrm{GPa}$ for $\mathrm{Ni}-5$. This may be due to the presence of soft nickel carbide nanoclusters in the hard amorphous a- $\mathrm{C}: \mathrm{H}$ matrix which changes the overall behavior of the film from diamond-like to graphite-like amorphous carbon thin film.

The friction and adhesion behavior of $\mathrm{a}-\mathrm{C}: \mathrm{H}$ and $\mathrm{Ni} / \mathrm{a}-\mathrm{C}: \mathrm{H}$ thin film with different Ni fractions were studied using nanoscratch test under ramping load from 0 to $1000 \mu \mathrm{N}$. Figure 8 shows the friction coefficient as a function of lateral displacement from 0 to $10 \mu \mathrm{m}$. In general, both the pure $\mathrm{a}-\mathrm{C}: \mathrm{H}$ and $\mathrm{Ni} / \mathrm{a}-\mathrm{C}: \mathrm{H}$ films posses low friction coefficient values. In addition to that, both the films are highly scratch resistant without any peel-off from the substrate at higher loads. The typical value of friction coefficient is 0.464 for pure a-C: $\mathrm{H}, 0.2458$ for $\mathrm{Ni}$ is 1 , and 0.04182 for $\mathrm{Ni}$ is 5 . It was clearly seen that the film with very high $\mathrm{Ni}$ content of around 3.8 at.\% shows a very low friction coefficient value compared to that of other films. Hence, these results indicate that $\mathrm{a}-\mathrm{C}: \mathrm{H}$ films are becoming more smooth with the increase in the incorporation of $\mathrm{Ni}$ content. Further, no scratch track was observed. Hence, it was clearly shown that the $\mathrm{Ni} / \mathrm{a}-\mathrm{C}: \mathrm{H}$ films prepared through RBTIBD method are highly smooth with good scratch resistance. (i) $\mathrm{a}-\mathrm{C}: \mathrm{H}$
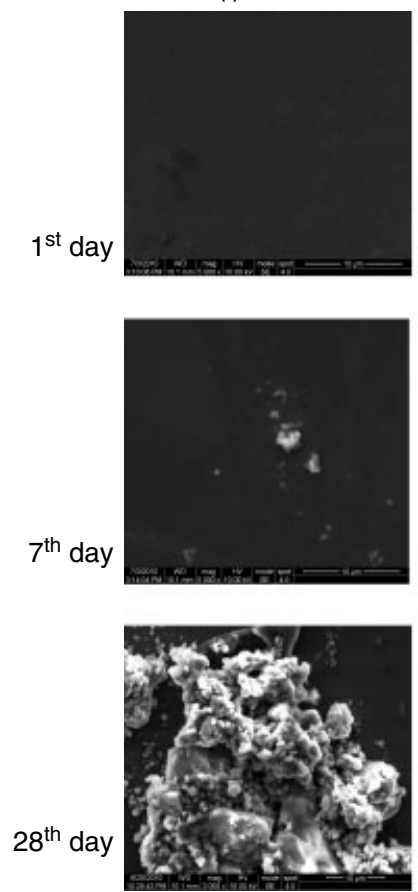

(ii) $\mathrm{Ni} / \mathrm{a}-\mathrm{C}: \mathrm{H}$
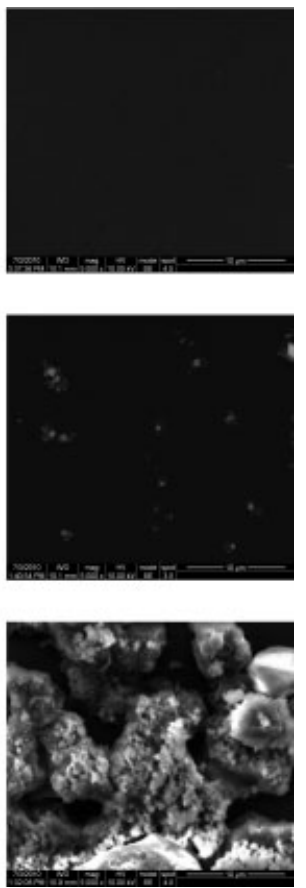

Figure 9. SEM photographs of the surfaces of (i) a-C:H and (ii) Ni/a-C:H thin films after immersing in the SBF solution for 1, 7 and 28 days.

\section{In vitro bioactivity analysis}

Biomimetic apatite coatings precipitated on the surface of a-C:H and $\mathrm{Ni} / \mathrm{a}-\mathrm{C}: \mathrm{H}(\mathrm{Ni}-2.4$ at.\%) thin film samples during the SBF treatment were analyzed by SEM and XRD. Figure 9 shows the SEM images of a-C:H and $\mathrm{Ni} / \mathrm{a}-\mathrm{C}: \mathrm{H}$ samples immersed in SBF solution and analyzed after 1,7 and 28 days of immersion. After $24 \mathrm{~h}$ of immersion, both the $\mathrm{a}-\mathrm{C}: \mathrm{H}$ and $\mathrm{Ni} / \mathrm{a}-\mathrm{C}: \mathrm{H}$ films have shown no formation of bone-like apatite on the surface. However, similar immersion for 28 days have resulted a dense apatite coverage over larger area on the $\mathrm{Ni} / \mathrm{a}-\mathrm{C}: \mathrm{H}$ films surface. In the case of pure $\mathrm{a}-\mathrm{C}: \mathrm{H}$, the apatite layer was formed with poor coverage. The observed result thus indicate a fact that the bioactivity of $\mathrm{a}-\mathrm{C}: \mathrm{H}$ gets improved because of the presence of metal clusters on the surface of nanocomposite thin film. It is usually believed that the $\mathrm{OH}$ functional groups formed on the surface of the thin film, play an important role in the nucleation of apatite. ${ }^{[33]}$ Recently, Qiwei et al. ${ }^{[34]}$ have investigated the bioactivity of surface-modified Titanium dioxide thin films and found that the $\mathrm{OH}$ group present on the film surface in the form of Ti-OH helps to initiate the growth of apatite. Similarly, enhanced bioactivity was noticed from Tantalum thin film which was again attributed to the formation of $\mathrm{Ta}-\mathrm{OH}$ on the film surface ${ }^{[35]}$ As XPS results have also shown the presence of $\mathrm{OH}$ group in the form of $\mathrm{Ni}-\mathrm{OH}$, such $\mathrm{OH}$ functional group formed on the films surface initiate the growth of apatite. Formation of bone-like apatite layer on the surface of the film promotes the bone bonding with living tissues and thereby helps to increase the longevity of the implant. To confirm the apatite composition, EDX analysis was performed. It was observed that the $\mathrm{Ca} / \mathrm{P}$ ratios of asgrown apatite is in accordance with nonstoichiometric biological apatite. $^{[36]}$

The phase composition and the crystallinity of the apatite formed on the film after exposure to SBF solution were investigated by XRD analysis. The as-grown apatite was scratched from the 


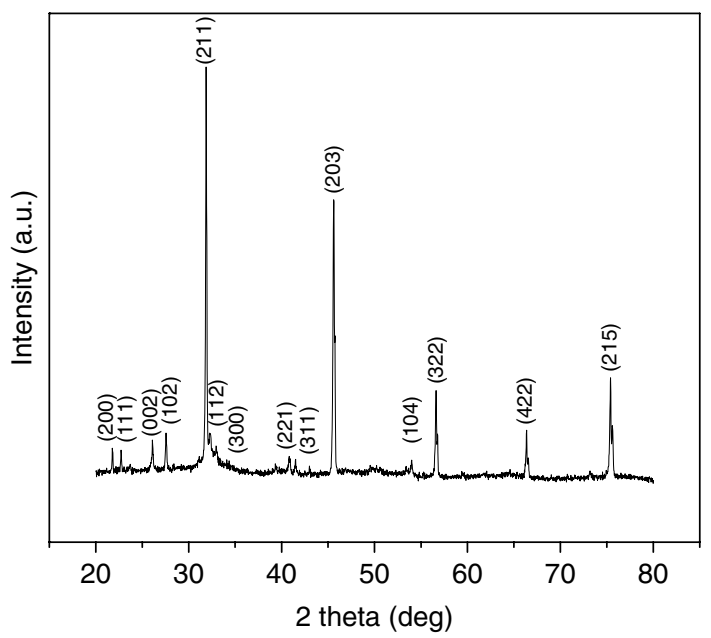

Figure 10. XRD spectra of apatite formed on the surface of the $\mathrm{Ni} / \mathrm{a}-\mathrm{C}: \mathrm{H}$ thin films after SBF soaking.

sample and its crystallinity was investigated. Figure 10 shows the XRD pattern of bone-like apatite grown on the surface of $\mathrm{Ni} / \mathrm{a}$ $\mathrm{C}: \mathrm{H}$ film after 28 days of immersion. It was clearly seen that the as-grown apatite was high-crystallinity hydroxyapatite (HAp). All the diffraction peaks were readily indexed to the pure hexagonal phase with lattice parameters of $a=9.418 \AA$ and $c=6.884 \AA$, which was in accordance with that of HAp crystals. (JCPDS card \# 09-0432).

\section{Conclusion}

Amorphous nickel incorporated hydrogenated carbon films with low Ni concentration ranging from 1.2 to 3.8 at.\% were synthesized by using RBTIBD method. It was observed that the elemental concentration of $\mathrm{Ni}$ in the films increased with an increase in the target bias voltage. At about 2.8 at. $\%$ of $\mathrm{Ni}$, uniform sized, randomly dispersed $\mathrm{NiC}$ nanoclusters were seen in the $\mathrm{a}-\mathrm{C}: \mathrm{H}$ matrix. These $\mathrm{NiC}$ clusters were $\mathrm{Ni}_{3} \mathrm{C}$ in phase at the core. However, at the top surface, the clusters were contaminated by atmospheric oxygen and, therefore, its oxide and hydroxide phases appeared. The presence of nickel hydroxide phase at the surface of $\mathrm{Ni} / \mathrm{a}-\mathrm{C}: \mathrm{H}$ film is the reason which favored the growth of apatite and increased the growth rate of the apatite layer. At the core, the presence of $\mathrm{NiC}$ nanoclusters have increased the $\mathrm{sp}^{2}$ content in the $\mathrm{a}-\mathrm{C}: \mathrm{H}$ matrix, which in turn reduced the mechanical hardness and friction coefficient of the Ni/a-C:H films. The result thus obtained provides valuable insights into the potential use of $\mathrm{Ni} / \mathrm{a}-\mathrm{C}: \mathrm{H}$ material to support apatite growth with promising mechanical properties suitable for bone cell growth on bone implants.

\section{Acknowledgments}

One of the authors, PVB, would like to thank the Government of Canada International Scholarship Programs for providing partial financial support.

\section{References}

[1] L. L. Hench, J. Am. Ceram. Soc. 1998, 81, 1705.

[2] T. Kokubo, H. Kushitani, S. Kitsugi, T. Yamamuro, J. Biomed. Mater. Res. 1990, 24, 721.

[3] T. Kokubo, S. Ito, Z. T. Huang, T. Hayashi, S. Sakka, T. Kitsugi, T. Yamamuro, J. Biomed. Mater. Res. 1990, 24, 331.

[4] Y. T. Pei, D. Galvan, J. Th. M. De Hosson, Acta Materialia 2005, 53, 4505.

[5] C. Corbella, G. Oncins, M. A. Gomez, M. C. Polo, E. Pascual, J. GarciaCespedes, J. L. Andujara, E. Bertran, Diamond Relat. Mater. 2005, 14, 1103.

[6] S. V. Hainsworth, N. J. Uhure, Int. Mater. Rev. 2007, 52, 153.

[7] Q. Zhao, Y. Liu, C. Wang, S. Wang, Diamond Relat. Mater. 2007, 16, 1682.

[8] A. Schroeder, G. Francz, A. Bruinink, R. Hauert, J. Mayer, E. Wintermantel, Biomaterials 2000, 21, 449 .

[9] A. D-Reisel, C. Schürer, V. Klemm, G. Irmer, E. Muller, Diamond Relat. Mater. 2003, 12, 1030.

[10] S. C. H. Kwok, P. C. T. Ha, D. R. McKenzie, M. M. M. Bilek, P. K. Chu, Diamond Relat. Mater. 2006, 15, 893.

[11] A. Bendavid, P. J. Martin, L. Randeniya, M. S. Amin, Diamond Relat. Mater. 2009, 18, 66.

[12] D. J. Li, L. F. Niu, Bull. Mater. Sci, 2003, 26, 371.

[13] K. Sedlackova, P. Lobotka, I. Vavra, G. Radnoczi, Carbon 2005, 43, 2192.

[14] S. Bhattacharyya, S. J. Henley, D. Lock, N. P. Blanchard, S. R. P. Silva, Appl. Phys. Lett. 2006, 89, 022113.

[15] G. Abrasonis, T. W. H. Oates, G. J. Kovacs, J. Grenzer, P. O. A. Persson, K. H. H. Heinig, A. Martinavicius, N. Jeutter, C. Baehtz, M. Tucker, M. M. M. Bilek, W. Moller, J. Appl. Phys. 2010, 108, 043503.

[16] J. L. Endrino, D. Horwat, R. Gago, J. Andersson, Y. S. Liu, J. Guo, A. Anders, Solid State Sci. 2009, 11(10), 1742.

[17] K. Ma, G. Yang, L. Yu, P. Zhang, Surf. Coat. Technol. 2010, 204, 2546.

[18] R. Koppert, D. Goettel, O. F-Weber, G. Schultes, Solid State Sci. 2009, $11,1797$.

[19] T. L. Hylton, B. Ciorneiu, D. A. Baldwin, O. Escorcia, J. Son, M. T. McClure, G. Waters, IEEE Trans. Magn. 2000, 36, 2966.

[20] J. J. Quan, S. A. Wolf, H. N. G. Wadley, J. Appl. Phys. 2007, 101, 074302.

[21] P. V. Bharathy, D. Nataraj, P. K. Chu, H.Wang, Q. Yang, M. S. R. N. Kiran, J. S-Albero, D. Mangalaraj, Appl. Surf. Sci. 2010, 257, 143.

[22] W. C. Oliver, G. M. Pharr, J. Mater. Res. 2004, 19, 3.

[23] A. M. Korsunsky, A. Constantinescu, Mater. Sci. Eng., A, 2006, 423, 28.

[24] J. R. Tuck, A. M. Korsunsky, D. G. Bhatc, S. J. Bull, Surf. Coat. Tech. 2001, 139, 63 .

[25] T. Kokubo, F. Miyaji, H. M. Kim, T. Nakamura, J. Am. Ceram. Soc. 1996, $79,1127$.

[26] F. Balas, T. Kokubo, M. Kawashita, T. Nakamura, J. Mater. Sci. Mater. Med. 2007, 18, 1167.

[27] C. Popov, W. Kulisch, S. Boycheva, K. Yamamoto, G. Geccone, Y. Koga, Diamond Relat. Mater. 2004, 13, 2071.

[28] Gy. J. Kovacs, I. Bertoti, G. Radnoczi, Thin Solid Films 2008, 516, 7942.

[29] G. Abrasonis, Gy. J. Kovacs, L. Ryves, M. Krause, A. Mucklich, F. Munnik, T.W. H. Oates, M. M. M. Bilek, W. Moller, J. Appl. Phys. 2009, 105, 083518.

[30] R. Anton, Carbon 2008, 46, 656.

[31] W. M. Huang, J. F. Su, M. H. Hong, B. Yang, Scripta Mater. 2005, 53, 1055.

[32] A. Kelly, N. H. Macmillan, Strong Solids, Clarendon, Oxford Press: 1986.

[33] T. Kokubo, Acta Mater. 1998, 46, 2519

[34] S. Qiwei, Z. Xiaoxia, W. Jiada, S. Jian, K. Ostrikov, Plasma Sci. Technol. 2009, $11,477$.

[35] T. Miyazaki, H.-M. Kim, T. Kokubo, C. Ohtsuki, H. Kato, T. Nakamur, Biomaterials 2002, 23, 827.

[36] S. V. Dorozhkin, Acta Biomater. 2010, 6, 715. 